Recommended by Doctor of Pharmacy, Professor V. S. Bondar

UDC $661.122+547.745+547.541$

\author{
N. O. Savina, N. M. Ocherethyana, V. M. Britsun, N. V. Ostanina
}

State Institution "O. M. Marzeyev Institute for Public Health of the National Academy of Medical Sciences of Ukraine"

\title{
Determination of related impurities in glimepiride tablets by the HPLC method
}

Glimepiride is one of the modern and effective drugs that counteract diabetes mellitus type 2. Like other drugs glimepiride must comply with quality standards set by relevant government departments.

Aim. To determine the content of related impurities in glimepiride tablets in order to assess the drug quality.

Materials and methods. The study was performed by the reversed-phase HPLC with a spectrophotometric detector in the isocratic mode, in the UV-region of the spectrum. To determine impurities the method of comparison with the solution having the known concentration of impurities and the active substance was used.

Results and discussion. It has been shown that the drug contains $\leq 0.18 \%$ of identified and unidentified impurities.

Conclusions. The purity of the drug complies with the requirements of normative documents.

Key words: glimepiride; tablets; quality control; diabetes mellitus type 2; HPLC; related impurities

Н. О. Савіна, Н. М. Очеретяна, В. М. Брицун, Н. В. Останіна

\section{Визначення методом ВEPX вмісту супутніх домішок у таблетках глімепіриду}

Одним із сучасних і ефективних ліків, що протидіють діабету 2-го типу, є глімепірид. Як і інші лікарські засоби, глімепірид повинен відповідати стандартам якості, встановленим уповноваженими державними установами.

Мета роботи - здійснення контролю якості супутніх домішок таблеток глімепіриду.

Матеріали та методи. Дослідження проводились методом обернено-фразової ВЕРХ на спектрофотометричному детекторі в ізократичному режимі з детектуванням в УФ-області спектра. Для визначення вмісту домішок був застосований метод порівняння з розчином, що має відому концентрацію домішок і основної речовини.

Результати та їх обговорення. Показано, що лікарський препарат містить $\leq 0,18$ \% ідентифікованих та неідентифікованих домішок.

Висновки. За перевіреним показником таблетки глімепіриду відповідають вимогам нормативних документів.

Ключові слова: глімепірид; таблетки; контроль якості; цукровий діабет 2-го типу; ВЕРХ; супутні домішки

Н. А. Савина, Н. Н. Очеретяна, В. Н. Брицун, Н. В. Останина

Определение методом ВЭЖХ содержания сопутствующих примесей в таблетках глимепирида

Глимепирид - современное лекарство, эффрективно противодействующее диабету 2-го типа. Как и другие лекарственные средства, глимепирид должен соответствовать стандартам качества, установленным уполномоченными государственными учреждениями.

Цель работы. Для оценки качества лекарства был проведен контроль содержания сопутствующих примесей в таблетках глимепирида.

Материалы и методы. Исследования осуществлялись методом обращенно-фазовой ВЭЖХ на спектрофотометрическом детекторе в изократическом режиме с детектированием в УФ-области спектра. Для установления содержания примесей использовался метод сравнения с раствором, содержащим известную концентрацию примесей и основного вещества.

Результаты и их обсуждение. Лекарственный препарат содержит $\leq 0,18$ \% идентифицированных и неидентифицированных примесей.

Выводы. Показано, что по проверенному показателю таблетки глимепирида соответствуют требованиям нормативных документов.

Ключевые слова: глимепирид; таблетки; контроль качества; сахарный диабет 2-го типа; ВЭЖХ; сопутствующие примеси

Diabetes is a chronic disease of the endocrine nature. It is a disorder of all types of metabolism of the human body [1]. Diabetes is a heavy social and economic burden, cause many complications and pathologies that reduce the efficiency and the life expectancy of the population of the average and preretirement age $[2,3]$.

Currently, more than 250 million people in the world have diabetes. The prevalence of diabetes in the population is $3-4 \%$, and it reaches $10-16 \%$ among middleaged adults in the Near East [1,2].
There is a persistent trend of increasing morbidity, which has an epidemic character. It is believed that due to the aging population, the number of patients over the next two decades will double [3].

In Ukraine diabetes was diagnosed for $2.8 \%$ of the population in 2014 [4]. Annually aproximately 100000 new cases of the disease are recorded.

The state projects for reducing the diabetes negative impact exist in many countries. In particular, the state target program "Diabetes mellitus" was functioned in 
Ukraine in 2009-2013 (CMU Resolution No. 877 from 19.09.2009) [5].

An insufficient production of insulin by the pancreas is the cause of the pathogenic effect of diabetes type 1, whereas expressed insulin inactivation or destruction of insulin receptors on membranes of the body cells is observed in the diabetes type 2 .

To control diabetes type 2 hypoglycemic agents drugs that reduce blood glucose levels are used. They are sulfonylureas (glibenclamide, glimepiride, tolbutamide, chlorpropamide), biguanides (metformin), thiazolidinone derivatives (troglitazone, rosiglitazone), alphaglucosidase inhibitors (acarbose and miglitol), dipeptidyl peptidase inhibitors (sitagliptin, vildagliptin), incretins [6].

One of the modern and effective drug to control diabetes type 2 is glimepiride, which triggers the insulin production by the pancreas, increases the number of insulin-sensitive receptors and inhibits gluconeogenesis [7, 8].

All medicines in Ukraine must meet quality standards, which are regulated by the State Pharmacopoeia of Ukraine, the documents of the State Expert Center of the MHP of Ukraine and the State Service of Ukraine on medicines and drug control. The quality control of medicines is carried out in the authorized analytical laboratories, which have the necessary equipment and the staff of the qualified professionals, certified and accredited in the relevant institutions [9].

Scheme 1 of the glimepiride synthesis based on the use of 5-dihydro-3-ethyl-4-methylpyrolin-2-one $\mathbf{1}$ as the starting reagent contains 5 stages [10].

Taking into account the multi-stage synthesis and possible deviations from the optimal storage conditions the substance and the finished dosage forms of glimepiride may contain compounds that are byproducts of formation and partial decomposition of the active substance (related impurities). They are pollutants because their content is strictly limited and requires mandatory control.
The aim of this work is to study the content of related impurities in glimepiride by HPLC for compliance with the requirements of normative documents.

\section{Materials and methods}

For the tests glimepiride tablets of foreign production were used.

The study was performed by the reversed-phase HPLC on an Agilent 1200 chromatograph with a spectrophotometric detector in the isocratic mode, in the UV-region of the spectrum using an Inertsil CAS-3V column (with the length of $250 \mathrm{~mm}$, the diameter of $4.6 \mathrm{~mm}$, the particle size of $5 \mathrm{~mm}$ ). The column temperature was $25^{\circ} \mathrm{C}$, the rate of the mobile phase $-1 \mathrm{ml} / \mathrm{min}, \lambda=228 \mathrm{~nm}$, the injection volume $-20 \mu$ l, the mobile phase - phosphate buffer: acetonitrile.

Sulfonamide solution: add $50 \mathrm{ml}$ of methanol to $39.92 \mathrm{mg}$ of the sulfonamide standard in a $100.0 \mathrm{~mL}$ volumetric flask, shake to dissolve and dilute to the volume with the same solvent.

Carbamate solution: add $50 \mathrm{ml}$ of methanol to $4.20 \mathrm{mg}$ of the carbamate standard in a $100.0 \mathrm{ml}$ volumetric flask, shake to dissolve and dilute to the volume with the same solvent.

Glimepiride solution: add $50 \mathrm{ml}$ of methanol to $4.12 \mathrm{mg}$ of the glimepiride standard in a $100.0 \mathrm{~mL}$ volumetric flask, shake to dissolve and dilute to the volume with the same solvent.

Reference solution for injections: pipette $2.0 \mathrm{ml}$ of solutions of sulfonamide, carbamate, glimepiride each in a $200.0 \mathrm{~mL}$ volumetric flask and dilute to the volume with methanol. The concentrations of sulfonamide, carbamate, glimepiride are 3.992, 0.42 and $0.412 \mathrm{mg} / \mathrm{ml}$, respectively.

Test solution of glimepiride: crush 20 tablets, weigh $599.43 \mathrm{mg}$ (equivalent to $10 \mathrm{mg}$ of glimepiride), transfer to a $25.0 \mathrm{ml}$ volumetric flask. Add $20 \mathrm{ml}$ of methanol, shake to dissolve, dilute to the volume with the same solvent and filter.<smiles>CCC1=C(C)CNC1=O</smiles><smiles>CCC1=C(C)CN(C(=O)NCCc2ccccc2)C1=O</smiles><smiles>CCC1=C(C)CN(C(=O)NCCc2ccc(S(=O)(=O)Cl)cc2)C1=O</smiles><smiles>CCC1=C(C)CN(C(=O)NCCc2ccc(S(=O)(=O)NC(C)=O)cc2)C1=O</smiles><smiles>CC1CCC(N)CC1</smiles><smiles>CCC1=C(C)CN(C(=O)NCCc2ccc(S(=O)(=O)NC(=O)N[C@H]3CC[C@H](C)CC3)cc2)C1=O</smiles> 
Table 1

The results of the chromatographic study of the standard solutions of sulfonamide, carbamate and glimepiride

\begin{tabular}{|c|c|c|c|c|c|c|}
\hline \multirow{2}{*}{ No. } & \multicolumn{2}{|c|}{ Sulfonamide } & \multicolumn{2}{c|}{ Carbamate } & \multicolumn{2}{c|}{ Glimepirid } \\
\cline { 2 - 7 } & Retention time, min & Peak area & Retention time, min & Peak area & Retention time, min & Peak area \\
\hline 1 & 6.483 & 337.485 & 8.971 & 32.004 & 34.083 & 27.770 \\
\hline 2 & 6.467 & 337.697 & 8.952 & 32.427 & 34.138 & 27.496 \\
\hline 3 & 6.479 & 339.370 & 8.963 & 32.210 & 34.020 & 27.655 \\
\hline Mean & 6.476 & 338.184 & 8.962 & 32.214 & 34.080 & 27.640 \\
\hline RSD, \% & 0.13 & 0.31 & 0.11 & 0.66 & 0.17 & 0.50 \\
\hline
\end{tabular}

Note: The peak resolution factor for sulfonamide and carbamate is 7.74-7.77.

The results of the chromatographic study of the reference and test solutions are shown in Tab. 1 and 2, respectively.

Statistical analysis of the results obtained and estimated uncertainty were carried out in accordance with the pharmacopoeial requirements (SPhU and $\mathrm{Ph}$. Eur.) $[11,12]$.

The chromatographic system suitability test corresponded to the requirements specified (the mean value of the symmetry factor for 5 parallel injections was within 1.04-1.05; the relative standard deviation of peak areas of the reference solution was less than $2.0 \%$, and the number of theoretical plates was $\geq 5000$ ).

\section{Results and discussion}

According to the data of the European Pharmacopoeia [12] the glimepiride substance can have not more than $0.9 \%$ of impurities, in particular identified compounds A-J (Scheme 2).

Compounds $\mathbf{B}$ (sulfonamide) and $\mathbf{C}$ (carbamate) are formed at the last stages of the glimepiride synthesis. They have similar solubility. These impurities are basic in the substance and medicines of glimepiride.

For glimepiride tablets under study the following requirements were set by manufacturer: the content of related impurities should be not more than $1.0 \%$ (for sulfonamide and carbamate - not more than 0.6 and $0.1 \%$, respectively).

For the quantitative determination of impurities the method of comparison with the standard solution containing the known concentration of impurities and the active substance was used The reference and test solutions were injected, and peak areas on the chromatograms were integrated, after that the content of impurities was calculated.

The test results are given in Tab. 1, 2. The chromatogram of the test solution of glimepiride is presented in Fig.

The content of sulfonamide (\%) was calculated using the formula:

$$
\mathrm{C}_{\text {sulf }}=\left(\mathrm{S}_{\text {inv }} / \mathrm{S}_{\mathrm{et}}\right) \times\left(\mathrm{m}_{\text {samp }} / 4\right) \times\left(1 / \mathrm{m}_{\mathrm{gl}}\right) \times(\mathrm{Av} / \mathrm{D}) \times \mathrm{P},
$$

where: $\mathrm{S}_{\text {inv }}$-is the average peak area of sulfonamide on the chromatogram of the test solution; $\mathrm{S}_{\mathrm{et}}-$ is the average

\begin{tabular}{|c|c|c|c|}
\hline No. & Substance & $\begin{array}{l}\text { Retention } \\
\text { time, min }\end{array}$ & Peak area \\
\hline \multirow{5}{*}{1} & \multirow{3}{*}{ Sulfonamide } & 6.465 & 42.153 \\
\hline & & 6.487 & 41.748 \\
\hline & & 6.498 & 41.936 \\
\hline & Mean & 6.483 & 41.946 \\
\hline & RSD, \% & 0.26 & 0.48 \\
\hline \multirow{5}{*}{2} & \multirow{3}{*}{ Carbamate } & 8.937 & 3.820 \\
\hline & & 8.966 & 3.773 \\
\hline & & 8.861 & 3.917 \\
\hline & Mean & 8.921 & 3.837 \\
\hline & RSD, \% & 0.61 & 1.91 \\
\hline \multirow{5}{*}{3} & \multirow{3}{*}{$\begin{array}{l}\text { Unidentified } \\
\text { impurity } 1\end{array}$} & 11.676 & 3.035 \\
\hline & & 11.728 & 3.119 \\
\hline & & 11.791 & 3.134 \\
\hline & Mean & 11.732 & 3.096 \\
\hline & $\mathrm{RSD}, \%$ & 0.49 & 1.72 \\
\hline \multirow{5}{*}{4} & \multirow{3}{*}{$\begin{array}{l}\text { Unidentified } \\
\text { impurity } 2\end{array}$} & 22.320 & 8.763 \\
\hline & & 22.421 & 8.574 \\
\hline & & 22.393 & 8.660 \\
\hline & Mean & 22.378 & 8.666 \\
\hline & RSD, \% & 0.23 & 1.09 \\
\hline \multirow{5}{*}{5} & \multirow{3}{*}{$\begin{array}{l}\text { Unidentified } \\
\text { impurity } 3\end{array}$} & 25.578 & 3.231 \\
\hline & & 25.665 & 3.320 \\
\hline & & 25.701 & 3.205 \\
\hline & Mean & 25.648 & 3.252 \\
\hline & RSD, \% & 0.25 & 1.85 \\
\hline \multirow{5}{*}{6} & \multirow{3}{*}{ Glimepiride } & 34.070 & 23678.3 \\
\hline & & 34.356 & 23698.5 \\
\hline & & 34.186 & 23681.1 \\
\hline & Mean & 34.204 & 23686.0 \\
\hline & RSD, \% & 0.42 & 0.05 \\
\hline
\end{tabular}

Note: the symmetry coefficient of peaks on the chromatograms is 1.01-1.20. 


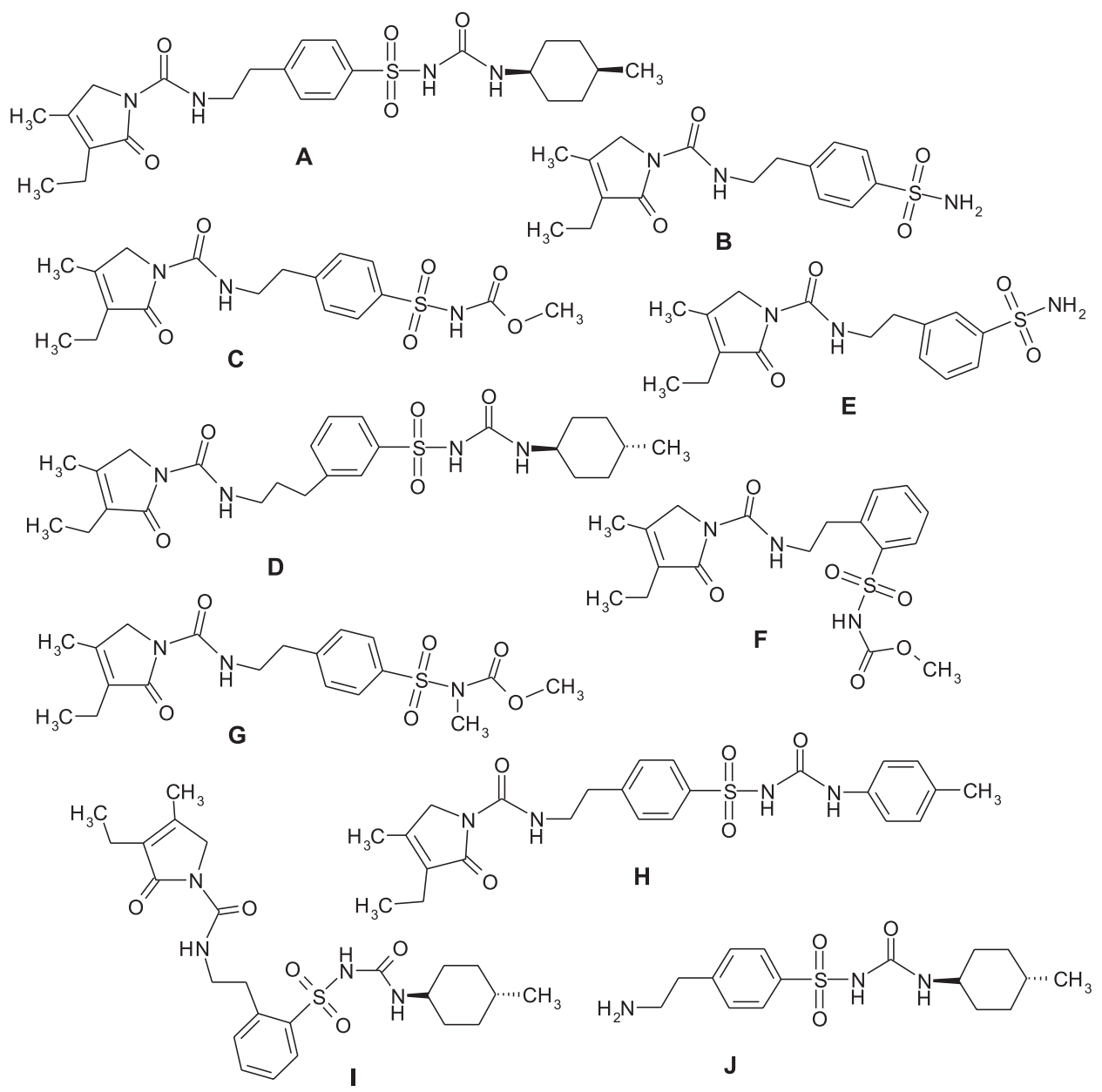

Scheme 2

peak area of sulfonamide on the chromatogram of the standard solution; $\mathrm{m}_{\text {samp }}-$ is the weight of the sulfonamide standard $(\mathrm{mg}) ; \mathrm{m}_{\mathrm{gl}}$ - is the weight of the glimepiride sample (599.43 mg); Av - is the average weight of tablets $(359.85 \mathrm{mg})$; D - is the labeled amount of glimepiride per tablet, $\mathrm{P}$ - is the purity of the standard sample of sulfonamide (0.991).

Calculation using digital data from Tab. 1, 2 and information from the experimental part shows that the sulfonamide content is $0.12 \%$.
The content of carbamate (\%) was calculated using the formula:

$$
\mathrm{C}_{\text {carb }}=\left(\mathrm{S}_{\text {inv }} / \mathrm{S}_{\mathrm{et}}\right) \times\left(\mathrm{m}_{\mathrm{st}} / 4\right) \times\left(1 / \mathrm{m}_{\mathrm{samp}}\right) \times(\mathrm{Av} / \mathrm{D}) \times \mathrm{P},
$$

where: $\mathrm{S}_{\text {inv }}$ - is the average peak area of carbamate on the chromatogram of the test solution; $\mathrm{S}_{\mathrm{et}}-$ is the average peak area of carbamate on the chromatogram of the standard solution; $\mathrm{m}_{\mathrm{st}}-$ is the weight of the carbamate sample $(\mathrm{mg}) ; \mathrm{m}_{\mathrm{samp}}$ - is the weight of the glimepiride sample (599.43 mg); $\mathrm{Av}$ - is

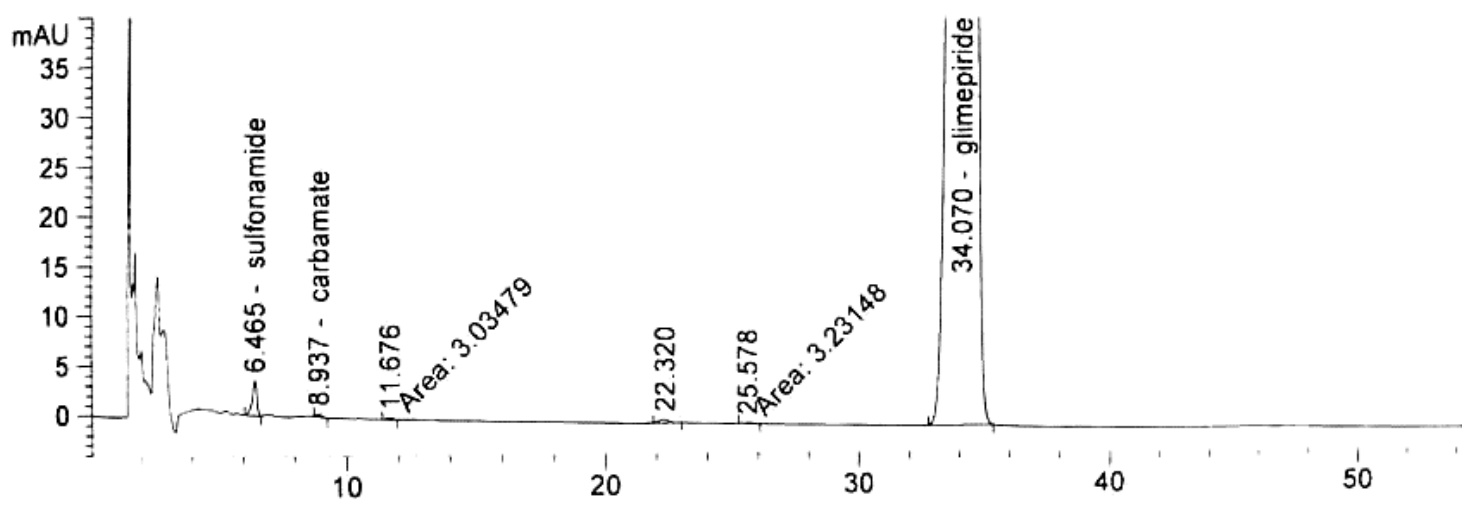


the average weight of tablets $(359.85 \mathrm{mg})$; $\mathrm{D}$ - is the labeled amount of glimepiride per tablet; $\mathrm{P}$ - is the purity of the standard sample of carbamate (0.969).

Calculation using data from Tab. 1, 2 and information from the experimental part indicates that the carbamate content is $0.01 \%$.

Calculation of the content of unidentified impurities was performed using the formula:

$$
\mathrm{C}_{\mathrm{un}}=\left(\mathrm{S}_{\mathrm{inv}} / \mathrm{S}_{\mathrm{g}}\right) \times\left(\mathrm{m}_{\mathrm{st}} / 4\right) \times\left(1 / \mathrm{m}_{\mathrm{samp}}\right) \times(\mathrm{Av} / \mathrm{D}) \times \mathrm{P},
$$

where: $S_{\text {inv }}$ - is the average peak area of the unidentified impurity on the chromatogram of the test solution; $\mathrm{S}_{\mathrm{gl}}-$ is the average peak area of glimepiride on the chromatogram of the standard solution; $\mathrm{m}_{\mathrm{st}}-$ is the weight of the glimepiride standard (mg); $\mathrm{m}_{\text {samp }}$ - is the weight of the glimepiride sample (599.43 mg); Av - is the average weight of tablets (359.85 mg); $\mathrm{D}$ - is the labeled amount of glimepiride per tablet; $\mathrm{P}$ - is the purity of the standard sample of glimepiride (0.995).
Calculation using data from the experimental part and Tab. 1.2 shows that the content of unidentified impurities $1-3$ is $0.01,0.03$ and $0.01 \%(0.05 \%$ of the total amount), respectively.

The total amount of impurities was calculated by the formula:

$$
\%_{\text {imp }}=\mathrm{C}_{\text {sulf }}+\mathrm{C}_{\text {carb }}+\mathrm{C}_{\text {unident }} .
$$

The total content of identified and unidentified impurities $1-3$ is $0.18 \%$. This is significantly less than the permitted value of $1.0 \%$.

\section{CONCLUSIONS}

Testing of glimepiride (tablets) on the content of related impurities by the HPLC method has shown that the drug meets the requirements of normative documents and is safe for consumers.

Conflicts of Interest: authors have no conflict of interest to declare.

\section{REFERENCES}

1. Внутрішні хвороби / Ред. М. С. Расін. - Полтава : Форміка, 2002. - 345 с.

2. Державна фармакопея України, Т. 1. - Х. : Український науковий фармакопейний центр якості лікарських засобів. - 2015. - 1128 с.

3. Лукьянчук, Е. // Еженедельник Аптека. - 2015. - № 48. - С. 1019. Режим доступу : http://www.apteka.ua/article/350970

4. Basit, A. Glimepiride : evidence-based facts, trends, and observations / A. Basit, M. Riaz, A. Fawwad // Vasc. Health Risk Manag. 2012. - Vol. 8. - P. 463-472. doi: 10.2147/vhrm.s33194

5. European Pharmacopoeia, Sixth Ed., Vol. 2. - Nordlingen : Druckerei C. H. Beck, 2008. - 1974 p.

6. Про затвердження Державної цільової програми «Цукровий діабет» : постанова Кабінету Міністрів України від 19 серпня 2009 р. № 877. - Режим доступу : http://zakon4.rada.gov.ua/laws/show/877-2009-\%D0\%BF

7. Державна науково-дослідна лабораторія з контролю якості лікарських засобів. - Режим доступу : http://www.druglab.kiev.ua/

8. Kahn, S. E. Pathophysiology and treatment of type 2 diabetes : Perspectives on the past, present, and future / S. E. Kahn, M. E. Cooper, S. D. Prato // The Lancet. - 2014. - Vol. 383, Issue 9922. - P. 1068-1083. doi: 10.1016/s0140-6736(13)62154-6

9. Olokoba, A. B. Type 2 Diabetes Mellitus : A Review of Current Trends / A. B. Olokoba, O. A. Obateru, L. B. Olokoba // Oman Med. J. - 2012. - Vol. 27, Issue 4. - P. 269-273. doi: 10.5001/omj.2012.68

10. Stefansson, E. Public health and prevention of blindness in diabetes / E. Stefansson, A. B. Einarsdottir // Int. J. Diabetes Mellitus. 2015. - Vol. 3, Issue 1. - P.1-3. doi: 10.1016/j.ijdm.2011.01.011

11. WO 2006103690 A1, PCT/IN2005/000164. A novel process for preparation of substantially pure glimepiride / Venkatasubramanian R. T., Suresh M. K., Sanjay J. N., Sachin B. G.; declared 18.05.2005 ; published 05.10.2006.

12. Comparative efficacy of glimepiride and metformin in monotherapy of type 2 diabetes mellitus : meta-analysis of randomized controlled trials / H. Zhu, Sh. Zhu, X. Zhang et al // Diabetol. Metab. Syndr. - 2013. - Vol. 5, Issue 1. - P. 70-74. doi: 10.1186/1758-5996-5-70

\section{REFERENCES}

1. Rasin, M. S. (2002). Vnutrishni khvoroby. Poltava: Formika, 345.

2. Derzhavna Farmakopeia Ukrainy (Second Ed., Vol. 1). (2015). Kharkiv: Ukrainskyi naukovyi farmakopeinyi tsentr yakosti likarskykh zasobiv, 1128.

3. Lukianchuk, E. (2015). Ezhenedelnik Apteka, 48, 1019. Available at: http://www.apteka.ua/article/350970

4. Basit, A., Riaz, M., Fawwad, A. (2012). Glimepiride: evidence-based facts, trends, and observations. Vascular Health and Risk Management, 8, 463-472. doi: 10.2147/vhrm.s33194

5. European Pharmacopoeia (Sixth Ed., Vol. 2). (2008). Nordlingen: Druckerei C. H. Beck, 1974.

6. Nakaz MOZ Ukrainy № 877 vid 19.08.2009. Pro zatverdzhennia Derzhavnoi tsilovoi prohramy «Tsukrovyi diabet». Available at : http:// zakon4.rada.gov.ua/laws/show/877-2009-\%D0\%BF

7. Derzhavna naukovo-doslidna laboratoriia z kontroliu yakosti likarskykh zasobiv. Available at: http://www.druglab.kiev.ua/

8. Kahn, S. E., Cooper, M. E., Prato, S. D. (2014). Pathophysiology and treatment of type 2 diabetes: Perspectives on the past, present, and future. The Lancet - 383 (9922), 1068-1083. doi: 10.1016/S0140-6736(13)62154-6

9. Olokoba, A. B., Obateru, O. A., Olokoba, L. B. (2012). Type 2 Diabetes Mellitus: A Review of Current Trends. Oman Medical Journal, 27 (4), 269-273. doi: 10.5001/omj.2012.68

10. Stefansson, E., Einarsdottir, A. B. (2015). Public health and prevention of blindness in diabetes. International Journal of Diabetes Mellitus, 3 (1), 1-3. doi:10.1016/j.ijdm.2011.01.011 
11. Venkatasubramanian, R. T., Suresh, M. K., Sanjay, J. N., Sachin, B. G. (2006). WO 2006103690 A1. A novel process for preparation of substantially pure glimepiride; declared 18.05.2005; published 05.10.2006.

12. Zhu, H., Zhu, Sh., Zhang, X., Guo, Y., Shi, Y., Chen, Zh. (2013). Comparative efficacy of glimepiride and metformin in monotherapy of type 2 diabetes mellitus: meta-analysis of randomized controlled trials. Diabetology \& Metabolic Syndrome, 5, 70-74. doi: 10.1186/1758-5996-5-70

\section{Information about authors:}

Savina N. O., researcher of the State Research Laboratory for Quality Control of Medicines, State Institution "O. M. Marzeyev Institute for Public Health of the National Academy of Medical Sciences of Ukraine”. E-mail: katrinsavina@ukr.net

Ocherethyana N. M., researcher of the State Research Laboratory for Quality Control of Medicines, State Institution "O. M. Marzeyev Institute for Public Health of the National Academy of Medical Sciences of Ukraine”. E-mail: 53277432006@ukr.net

Britsun V. M., Doctor of Chemistry (Dr. habil.), chief researcher of the State Research Laboratory for Quality Control of Medicines, State Institution “

O. M. Marzeyev Institute for Public Health of the National Academy of Medical Sciences of Ukraine"

Ostanina N. V., Candidate of Economics (Ph.D.), researcher, head of the State Research Laboratory for Quality Control of Medicines, State Institution “

O. M. Marzeyev Institute for Public Health of the National Academy of Medical Sciences of Ukraine". E-mail: 3526309@ukr.net

Відомості про авторів:

Савіна Н. О., науковий співробітник, Інститут громадського здоров’я ім. О. М. Марзєєва Національної академії медичних наук України.

E-mail: katrinsavina@ukr.net

Очеретяна Н. М., науковий співробітник, Інститут громадського здоров’я ім. О. М. Марзєєва Національної академії медичних наук України.

E-mail: 53277432006@ukr.net

Брицун В. М., д-р хім. наук, головний науковий співробітник, Інститут громадського здоров’я ім. О. М. Марзєєва Національної академії медичних наук

України. E-mail: 3526309@ukr.net; britsun167@ukr.net

Останіна Н. В., канд. екон. наук, науковий співробітник, завідувач Державної науково-дослідної лабораторії $з$ контролю якості лікарських засобів, Інститут громадського здоров’я ім. О. М. Марзєєва Національної академії медичних наук України. E-mail: 3526309@ukr.net

Сведения об авторах:

Савіна Н. А., научный сотрудник, Институт общественного здоровья им. А. Н. Марзеева Национальной академии медицинских наук Украины.

E-mail: katrinsavina@ukr.net

Очеретяна Н. Н., научный сотрудник, Институт общественного здоровья им. А. Н. Марзеева Национальной академии медицинских наук Украины. E-mail: 53277432006@ukr.net

Брицун В. М., д-р хим. наук, главный научный сотрудник, Институт общественного здоровья им. А. Н. Марзеева Национальной академии медицинских наук Украины. E-mail: 3526309@ukr.net; britsun167@ukr.net

Останіна Н. В., канд. экон. наук, научный сотрудник, заведующая Государственной научно-исследовательской лабораторией по контролю качества лекарственных средств, Институт общественного здоровья им. А. Н. Марзеева Национальной академии медицинских наук Украины.

E-mail: 3526309@ukr.net 